\title{
Effect of calcium on the interaction of Acinetobacter baumannii with human respiratory epithelial cells
}

\author{
Yi Chen ${ }^{1,2 \dagger}$, Tingjun Shao ${ }^{1 \dagger}$, Sanhua Fang ${ }^{3}$, Ping Pan ${ }^{1}$, Jiahui Jiang ${ }^{1}$, Tongtong Cheng ${ }^{1}$, Haitong Wan ${ }^{4}$ and \\ Daojun $Y u^{1,3,4^{*}}$
}

\begin{abstract}
Background: Investigating the factors that influence Acinetobacter baumannii(Ab) adhesion/invasion of host cells is important to understand its pathogenicity. Metal cations have been shown to play an important role in regulating the biofilm formation and increasing the virulence of $\mathrm{Ab}$; however, the effect of calcium on host-bacterial interaction has yet to be clarified. Here, the dynamic process of the interaction between Ab and human respiratory epithelial cells and the effect of calcium on host-bacterial interaction were explored using microscopic imaging, quantitative PCR and real time cellular analysis (RTCA).

Results: The concentration of calcium, multiplicity of infection and co-culture time were all demonstrated to have effects on host-bacterial interaction. A unique "double peak" phenomenon changed to a sharp "single peak" phenomenon during the process of Ab infection under the effect of calcium was observed in the time-dependent cell response profiles. Moreover, calcium can increase Ab adhesion/invasion of epithelial cells by regulating the expression of Ab-related genes (ompA, bfmRS, abal).
\end{abstract}

Conclusions: Effective control of calcium concentrations can provide new approaches for the prevention and treatment of multi-drug resistant Ab.

Keywords: Acinetobacter baumannii, Calcium; host-bacterial interaction, Infection

\section{Background}

Over the last decades, Acinetobacter baumannii(Ab) has ranked among the most important Gram-negative nosocomial pathogens worldwide because of its increased rate of clinical isolation and the continuous emergence of multidrug-resistant strains $[1,2]$. Ab is known for its prolonged survival in hospital settings, owing to its great capacity to adhere to abiotic or biotic surfaces (e.g., human respiratory epithelial cells) and its high tolerance to varied environmental conditions [3, 4]. Thus $\mathrm{Ab}$ is forecasted to become one of the biggest challenges to health care. The adhesion of Ab to epithelial cells is considered an essential first step in

\footnotetext{
*Correspondence: yudaojun98@163.com

${ }^{\dagger}$ Yi Chen and Tingjun Shao contributed equally to this work.

${ }^{1}$ Hangzhou First People's Hospital, Zhejiang Chinese Medical University, Hangzhou, China

${ }^{3}$ Zhejiang University School of Medicine, Hangzhou, China

Full list of author information is available at the end of the article
}

colonization and infection. Colonization or infection with $\mathrm{Ab}$ occurs mostly in critically ill patients and causes severe pneumonia or bloodstream infections that result in increased in morbidity and mortality in these patients, which is a troublesome problem for clinical diagnosis, treatment and prevention $[1,5,6]$. Moreover, it is important to emphasize that colonization with $\mathrm{Ab}$ is more common than infection, even in susceptible populations [5, 7-9]. Although the pathogenicity of $\mathrm{Ab}$ is generally low, bacterial colonization is the greatest risk factor for nosocomial infection. Once the balance between host and microbes tips towards infection, results are often severe and frequently lead to an increased probability of Ab hospital outbreaks. Therefore, the research on the control of $\mathrm{Ab}$ infection and colonization is of great practical significance and value.

In view of the seriousness of the antibiotic resistance and mass colonization by $\mathrm{Ab}$ on biotic surfaces, the

(c) The Author(s). 2019 Open Access This article is distributed under the terms of the Creative Commons Attribution 4.0 International License (http://creativecommons.org/licenses/by/4.0/), which permits unrestricted use, distribution, and 
pathogenicity of Ab has aroused widespread concern, especially in regard to the host-bacteria interaction and the process and molecular mechanism of $\mathrm{Ab}$ adhesion/ invasion of human respiratory epithelial cells. Hostbacterial interaction is affected by many factors including biofilm formation and endotoxin production. In addition, biofilm formation represents an important factor associated with virulence and is affected by bacterial fimbriae, outer membrane proteins, adhesins, metal ions, quorum sensing, and complex regulatory networks (e.g., two-component regulatory systems), among others [10]. Investigating the factors affecting $\mathrm{Ab}$ adhesion/invasion of epithelial cells is important to understand its pathogenicity.

Metal cations have been shown to play an important role in regulating biofilm formation and differential expression of Ab-related genes, as well as in increasing the virulence of $\mathrm{Ab}$ and its ability to adhere to epithelial cells; however, the effects of calcium on host-bacterial interaction has not been elucidated [11, 12]. Studies have shown that bacterial infection can lead to a destabilization of the cellular calcium homeostasis and the activation of the calpain system ultimately triggering cell death, which suggests that changing the concentration of calcium in the environment may have a significant impact on the pathogenicity of $\mathrm{Ab}$ [13]. Lee et al. showed that bacterial attachment and biofilm formation on human respiratory epithelial cells and plastic surfaces were markedly reduced in the presence of the chelating agent EDTA (which effectively lowers the availability of metal cations such as $\mathrm{Ca}^{2+}$ and $\mathrm{Mg}^{2+}$ ) through the analysis of a group of multidrug-resistant Ab clinical isolates [14]. These data suggested that high concentrations of calcium may promote biofilm formation of $\mathrm{Ab}$ and enhance its adhesion to respiratory epithelial cells. However, this work did not specify the effect of calcium. It is important to explore the effect of calcium on host-bacterial interaction and to elucidate the functional mechanism, thus making it possible to take effective measures to control bacterial biofilm formation, adhesion and invasion and to ultimately provide new ideas for addressing the challenges of colonization and infection with multidrug-resistant $\mathrm{Ab}$.

A label-free and noninvasive detection system (RTCA S16 system, ACEA Biosciences Inc.) based on dynamical and quantitative monitoring of cellular impedance in real time can produce specific time-dependent cell response profile (TCRPs) patterns. This approach can provide biological information related to cellular physiological function for the study of host-bacterial interaction [15]. Therefore, in this work, we developed microscopic imaging, quantitative PCR (qPCR) and TCRP methods for continuously monitoring the interaction between $\mathrm{Ab}$ and human respiratory epithelial cells and the effect of calcium on host-bacterial interaction. Our research can be used to study the calciummediated signaling pathway in human respiratory epithelial cells infected with $\mathrm{Ab}$, which provides a basis for the study of the pathogenicity of Ab [16].

\section{Results \\ Optimum multiplicity of infection (MOI) of Ab to human respiratory epithelial cells}

The effects of $\mathrm{Ab}$ on the morphology and proliferation of human respiratory epithelial cells at different MOIs and co-culture time points were determined by inverted microscopy and are shown in Table 1 and Fig. 1A. After host-bacterial co-culture for $2 \mathrm{~h}$, therewere relatively few bacteria and almost no adhesion to epithelial cells. The differences between the groups were also relatively small (especially in the control group and the MOI 1 and MOI 10 experimental groups). After co-culture for approximately $4 \mathrm{~h}$, the differences betweenthe groups became more obvious. With the increase of MOI, the effect of $\mathrm{Ab}$ on the epithelial cells was also increased (the differences between the MOI 50 and MOI 100 experimental groups were not obvious). Additionally, compared with other co-culture time points, the changes in cell morphology and proliferation at $4 \mathrm{~h}$ of co-culture were more typical. Therefore, the co-culture time point of $4 \mathrm{~h}$ was selected as the appropriate time point for subsequent studies. In addition, at $6-8 \mathrm{~h}$ of co-culture, the quantity of bacteria was relatively large, which was not suitable for further research and analysis.

Bacterial invasion (including strong adhesion) to epithelial cells at different MOIs was determined by qPCR. The host cells and bacteria were co-cultured for $4 \mathrm{~h}$ and $1 \times 10^{5}$ cells were isolated for qPCR. The qPCR results (threshold cycles, Ct values) are shown in Fig. 1B. With the increase of MOI, the invasion of $\mathrm{Ab}$ into human respiratory epithelial cells increased gradually (the smaller the $\mathrm{Ct}$ value was, the more bacterial invasion occurred). There was no invasion in the control group. The difference in the $\mathrm{Ct}$ values among all the experimental groups was statistically significant $(P<0.05)$. MOI 100 group (Ct values: $23.56 \pm 0.04)<$ the MOI 50 group $(24.31 \pm$ $0.05)<$ the MOI 10 group $(27.36 \pm 0.05)<$ the MOI 1 group $(30.26 \pm 0.11)$. The difference in the $\mathrm{Ct}$ values between the MOI 10 and MOI 50 groups or between the MOI 1 and MOI 10 groups was approximately 3, while the difference between the MOI 50 and MOI 100 groups was relatively small (an approximately 0.8 difference in the Ct values).

TCRPs were determined by real time cellular analysis. The cell index (CI) induced by $\mathrm{Ab}$ infection increased at first and then decreased (Fig. 1C). With the decrease of MOI, the time to reach the peak CI was gradually delayed and the peak $\mathrm{CI}$ was also gradually increased. A 
Table 1 Microscopy observations of the effect of Ab on epithelial cells at different MOls

\begin{tabular}{|c|c|c|c|c|c|}
\hline \multirow{2}{*}{$\begin{array}{l}\text { Co- } \\
\text { culture } \\
\text { time } \\
\text { point }\end{array}$} & \multirow{2}{*}{$\begin{array}{l}\text { Control } \\
\text { group }^{a}\end{array}$} & \multicolumn{4}{|c|}{ Experimental group ${ }^{b}$} \\
\hline & & $\mathrm{MOI} 1$ & MOI 10 & MOI 50 & MOI 100 \\
\hline $2 \mathrm{~h}$ & $+1-$ & $+(-) / \pm(-)$ & $+(-) /++(-)$ & $+(+) / \&(+)$ & $+(+) / \&(+)$ \\
\hline $4 \mathrm{~h}$ & $++/-$ & $++(-) /+(-)$ & $++( \pm) /+++(-)$ & $++(++) / \& \&(++)$ & $++(++) / \& \&(++)$ \\
\hline $6 \mathrm{~h}$ & $+++/-$ & $+++(-) /++(-)$ & $+++(+) /++++(-)$ & $+++(+++) / \& \& \&(+++)$ & $+++(+++) / \& \& \&(+++)$ \\
\hline $8 \mathrm{~h}$ & $++++/-$ & $++++(-) /++(-)$ & $++++(+) /++++( \pm)$ & $+++(+++) / \& \& \& \&(+++)$ & $+++(+++) / \& \& \& \&(+++)$ \\
\hline
\end{tabular}

Control: $0.45 \% \mathrm{NaCl}$

${ }^{a}$ : epithelial cells / bacteria; ${ }^{\text {b }}$ : epithelial cells (bubble-like dead cells) / bacteria (bacterial aggregation phenomenon)

+: indicated the degree (the epithelial cells were expressed as the situation of adherent growth, bacteria were expressed as quantity, bubble-like dead cells and bacterial aggregation phenomenon were expressed as visibility); \&: indicated the degree $>++++;-$ indicated none

For example: $+/$ - indicated that a few of epithelial cells adhered to plates without bacteria; $+++(+++) / \& \& \&(+++)$ indicated that the bacterial number increased and the bacterial aggregation phenomenon became more obvious compared to $4 \mathrm{~h}$, a lot of epithelial cells adhered to plates and the bubble-like dead cells with bacterial adhesion visible

unique "double peak" phenomenon emerged in the process of infection (the smaller the MOI was, the more obvious the phenomenon was). The bacterial concentration of the MOI 50 experimental group was most appropriate, and the phenomenon characteristics were more typical than that in MOI 100 group. Therefore, the bacterial concentration $\left(1 \times 10^{8} \mathrm{CFU} / \mathrm{ml}\right)$ corresponding to the MOI 50 was suitable for subsequent studies based on the above results.

\section{Effect of $\mathrm{Ab}$ on different incubation states of human respiratory epithelial cells}

$\mathrm{Ab}$ had an almost identical effect on the different incubation states of epithelial cells (Fig. 2A). In the early stages of host-bacterial co-culture, epithelial cells can adhere to the plastic surface, although bubble-like dead cells (nuclear pyknosis, cell swelling anddissolution, Additional file 1: Figure S1) can be seen (after approximately $4 \mathrm{~h}$ ). However, with the prolongation of coculture time and the increase of the number of bacteria, the changes in cell morphology and proliferation, as well as the bacterial aggregation phenomenon became more typical (full field of bacteria after $8 \mathrm{~h}$ ). It was observed that $\mathrm{Ab}$ had an effect on the adherent growth of epithelial cells. After $24 \mathrm{~h}$, the bacteria dominated the entire cell culture dish, while the host cells were all dead.

The dynamic processes (as determined based on the TCRPs) of the interaction between $\mathrm{Ab}$ and epithelial cells in different states of cell incubation were also similar (Fig. 2B). For instance, the initial Ab infection had little effect on cell growth, and the "double peak" phenomenon emerged during $\mathrm{Ab}$ infection (this was not typical when the CI was about to enter the platform period). Almost identical cell growth curves were observed for the $0.45 \%$ sodium chloride solution $(\mathrm{NaCl})$ and sterile distilled water groups. Compared with the untreated group, the slight decrease or increase of CI in $0.45 \% \mathrm{NaCl}$ and sterile distilled water groups may have been associated with the dilution of nutrients or metabolites in the culture medium. Therefore, the effect of $0.45 \% \mathrm{NaCl}$ in the bacterial suspension on the adherent growth of epithelial cells could be considered negligible.

\section{Effect of calcium on Ab proliferation and biofilm formation}

As shown in Fig. 3, we found that high concentrations of calcium could contribute to the proliferation of $\mathrm{Ab}$ and that this effect was more pronounced with time. There was a difference in biofilm formation between $\mathrm{Ab}$ and $\mathrm{Ab}$-ompA ${ }^{-}$isolates $(P=0.00)$, indicating ompA had a significant effect on biofilm formation. Ab deficient in ompAcould reduce biofilm formation. Additionally, the results showed that calcium concentration was effective as a treatment factor $(P=0.00)$, calcium may promote biofilm formation. The bacterial biofilm formation was more obvious with the increase of calcium concentration (Fig. 4).

\section{Effect of calcium on the morphology and proliferation of human respiratory epithelial cells}

It was difficult to distinguish differences between the groups using inverted microscopy, so we next used TCRPs to evaluate the effects of calcium on the proliferation of human respiratory epithelial cells. The CI of epithelial cells increased significantly with both increasing calcium concentrations $(\leq 4.4 \mathrm{mmol} / \mathrm{L})$ and culture times $(\leq 24 \mathrm{~h})$ (Additional file 2: Figure S2). The CI values of each group under different calcium concentrations and culture times $(0 \mathrm{~h}, 2 \mathrm{~h}, 4 \mathrm{~h}, 6 \mathrm{~h}, 8 \mathrm{~h}, 12 \mathrm{~h}$ and $24 \mathrm{~h})$ were compared by multivariate ANOVA with repeated measures and the SNK test. The results showed that time was effective as a factor $(P=0.00)$, meaning that $\mathrm{CI}$ changes with time. There was a positive interaction between time and treatment (calcium concentrations) factors $(P=0.00)$. Exogenous calcium supplementation can promote the growth of human respiratory epithelial cells (Additional file 3: Table S1). The higher the calcium 
A
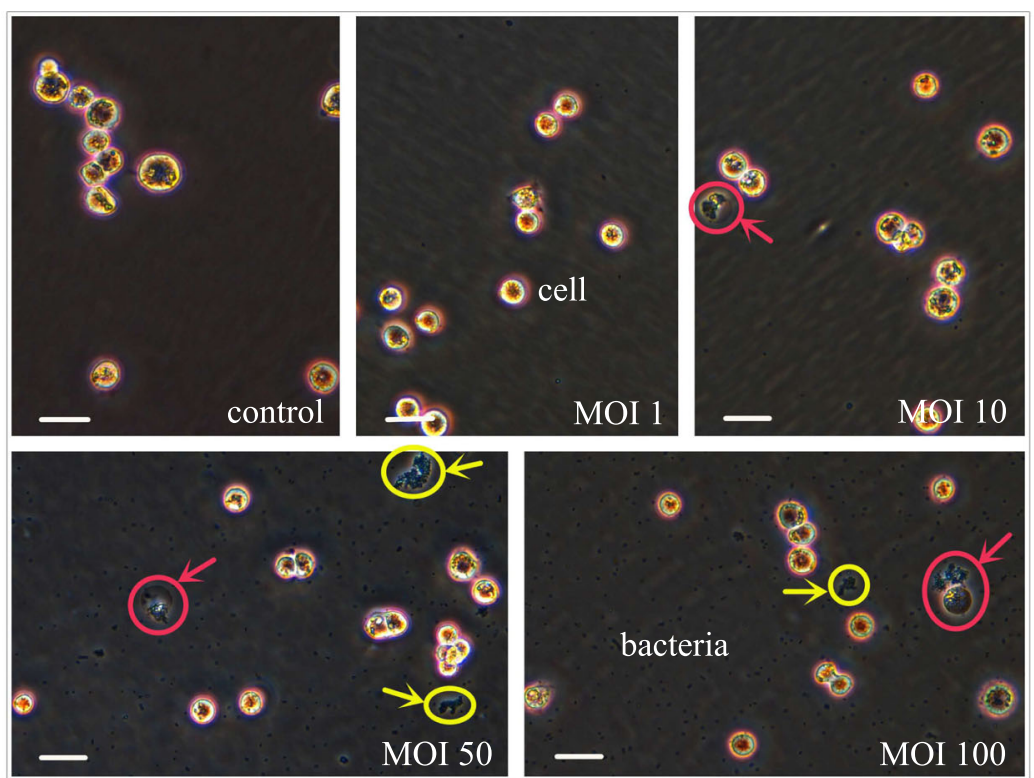

B

C
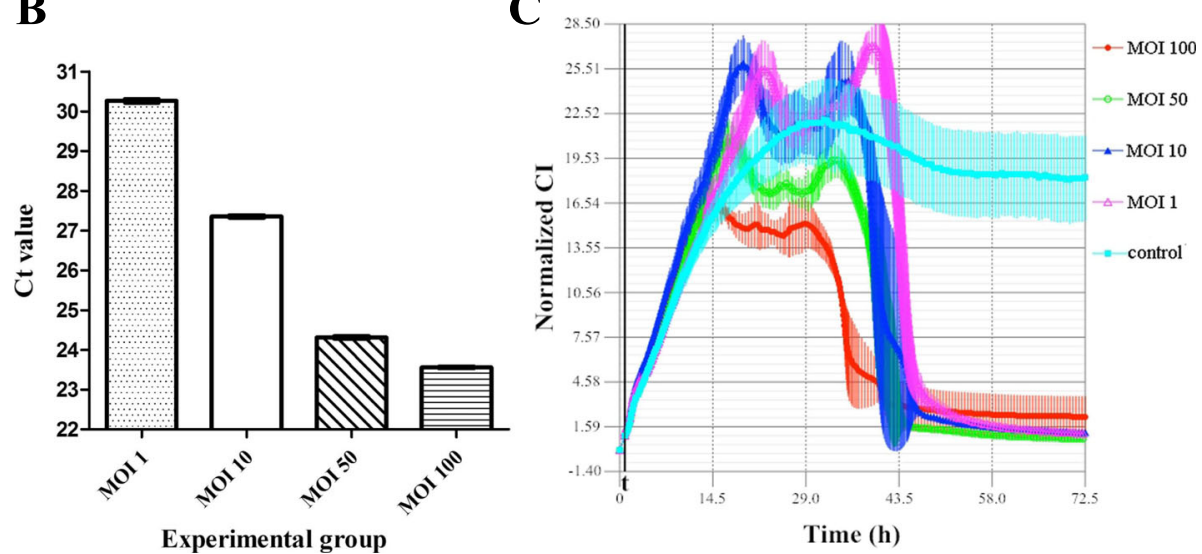

Fig. 1 Analysis of optimum $\mathrm{MOI}$ of Ab to human respiratory epithelial cells. Control: $0.45 \% \mathrm{NaCl}$. a Microscopy observations of the effect of $\mathrm{Ab}$ on epithelial cells $\left(2 \times 10^{5}\right.$ cells per well) at different MOls (co-cultured for $4 \mathrm{~h}$ ). Scale bar $=30 \mu \mathrm{m}$. Red arrows: bubble-like (denucleated) dead cells with bacterial adhesion visible around (especially in the $\mathrm{MOI} 50$ and $\mathrm{MOI} 100$ experimental groups); Yellow arrows: the phenomenon of bacterial aggregation. $\mathbf{b}$ The GPCR results indicating Ab invasion of epithelial cells (including strong adhesion) at different MOls (host cells and bacteria were co-cultured for $4 \mathrm{~h}$ and $1 \times 10^{5}$ cells were isolated). The differences in the Ct values (MOI 100 group $<\mathrm{MOI} 50$ group $<\mathrm{MOI} 10 \mathrm{group}<\mathrm{MOI}$ 1 group) among all the groups were statistically significant, as determined by the SNK test $(P<0.05)$. The differences between the MOI 1 and MOI 10 groups and the MOI 10 and $\mathrm{MOI} 50$ groups were greater than between the $\mathrm{MOI} 50$ and $\mathrm{MOI} 100$ groups. The higher the MOI was, the greater the Ab invasion of epithelial cells. c Ab infection TCRPs of epithelial cells (20,000 cells per well) at different MOls. t: point at which bacteria or $\mathrm{NaCl}$ were added (after background readings for the E-Plate were obtained and the plate was incubated at room temperature for 30 min). The "double peak" phenomenon emerged during Ab infection. The smaller the MOI was, the later and higher the peak $\mathrm{Cl}$ was, the more significant the phenomenon was. Representative curves are an average of three replicate wells

concentration was $(\leq 4.4 \mathrm{mmol} / \mathrm{L})$ and the longer the culture time was $(\leq 24 \mathrm{~h})$, the more significant the promoting effect on $\mathrm{CI}$ values was.

\section{Effect of calcium on host-bacterial interaction}

The role of calcium in bacterial proliferation was the same as has been described above. With the increase of co-culture time and calcium concentrations, the bacterial aggregation phenomenon (biofilm formation) became more obvious (Additional file 4: Figure S3). After $8 \mathrm{~h}$, there was an obvious increase in the quantity of bacteria. After approximately $24 \mathrm{~h}$, the bacteria encompassed the full field, while massive numbers of host cells were dead. It is known that $\mathrm{Ab}$ can have effects on the adherent growth of epithelial cells; however, the effects of calcium on the interactions between $\mathrm{Ab}$ and epithelial cells could not be determined using an inverted microscopy.

The host and bacteria were co-cultured in calciumsupplemented medium for $2 \mathrm{~h}, 4 \mathrm{~h}$ and $6 \mathrm{~h}$. The effects of calcium on bacterial invasion (including strong 


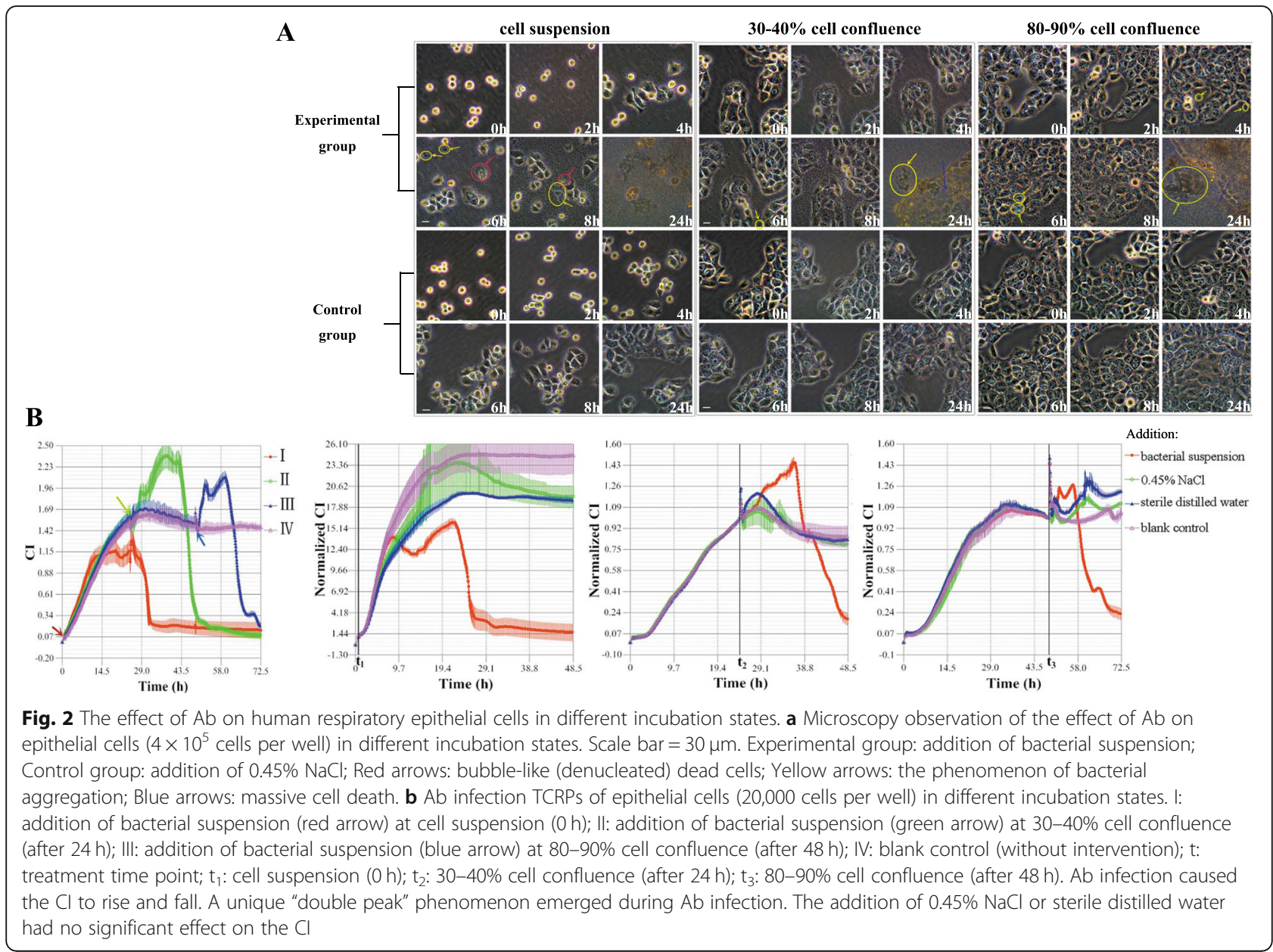

adhesion) of epithelial cells $\left(1 \times 10^{5}\right.$ cells as the standard $)$ were determined using qPCR and shown in Fig. 5. The results of control group II were negative. The Ct values were compared by univariate ANOVA with repeated measures and the SNK test. Time as a factor was significant with a $P=0.00$, which meant that the amount of $\mathrm{Ab}$ invading (including tightly adhered to) epithelial cells changed over time. Moreover, treatment (calcium concentrations) as a factor was effective $(P=0.00)$, meaning that the amount of $\mathrm{Ab}$ invading (including tightly adhered to) epithelial cells varied according to grouping, and this difference among the groups was statistically significant $(P<0.05)$. There was a positive correlation between the time and treatment factors $(P=0.00)$. The role of time as a factor varied from group to group. As a result, the higher the calcium concentration was and the longer the co-culture time was, the more frequently $\mathrm{Ab}$ invaded epithelial cells.

TCRPs showed that either initial Ab infection or the action of calcium could induce the increase of CI. When increasing calcium concentration in host and bacteria culture medium $(\leq 4.4 \mathrm{mmol} / \mathrm{L})$, the faster the CI rose, the higher the peak CI was $(6-8 \mathrm{~h})$, and the more significant cell growth stimulation was. By contrast, the CI declined rapidly with prolonged hostbacterial interactions (the higher the calcium concentration was, the faster the CI declined). Meanwhile, a sharp "single peak" phenomenon occurred in the process of infection (Fig. 6).

\section{Effect of calcium on the expression of Ab-related genes}

Calcium can affect the expression of Ab-related genes. TherecA gene was used as an internal reference control. Both negative controls (I and II) had no amplification. Relative changes in the expression levels of target genes (ompA, bfmRSandabaI) between experimental groups and control I group were calculated by the $2^{-\Delta \Delta \mathrm{Ct}}$ method. The trends were different between the abiotic and cellular environments that the bacteria were cultured in (Fig. 7).

There was no significant difference in the expression level of ompA among the groups cultured in the abiotic environment $(P>0.05)$, whereas expression of this gene showed significant differences in the cellular environment $(P<0.05)$. In the cellular environment, relative changes in expression levels between group $\mathrm{c}$ and 


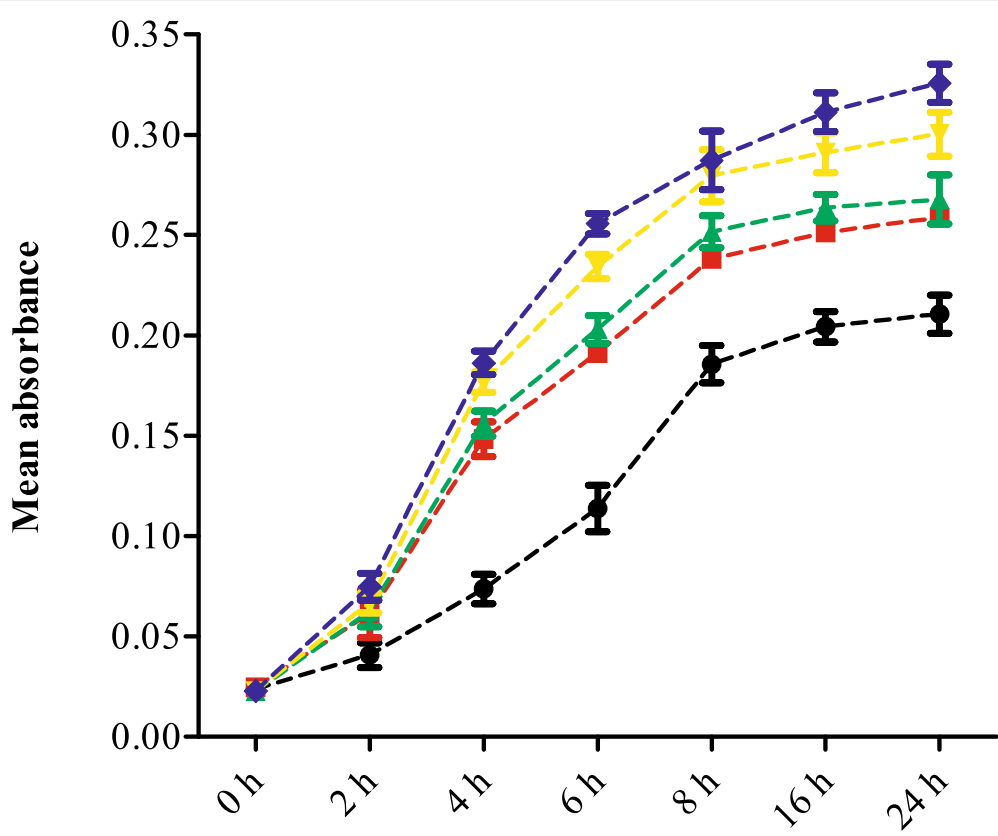

Time

$\rightarrow$ control I

\section{Calcium supplementation final concentration:}

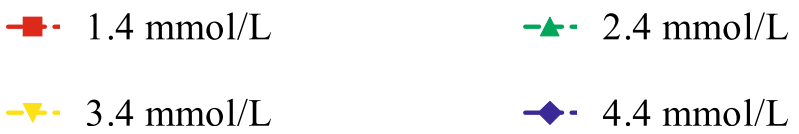

Fig. 3 The effect of calcium on Ab proliferation (growth curves). Control I: calcium final concentration was 0 mmol/L (with EDTA treatment).Calcium can promote the proliferation of $\mathrm{Ab}$

control I, as well as between group $\mathrm{d}$ and control I were small $(P>0.05)$; however, ompA expression in group b was approximately 4 -fold higher than that of the control I group.

In abiotic environment, there were significant differences in the expression ofbfmRS between the experimental groups and the control I group $(P<0.05)$. With the increase of calcium concentration in the culture medium, bfmRS expression in the experimental groups showed a decreasing trend; its expression in group $d$ was approximately 0.31 -fold higher than that of the control I group. In the cellular environment there was no significant difference in the expression level between group a and the control I group $(P>0.05)$. Contrary to the expression trend in the abiotic environment, expression level of groups b and c were approximately 2.3-fold higher than that of the control I group, while that of group $d$ was approximately 4 -fold higher.
In the abiotic environment, the expression level of $a b a I$ in group b, $\mathrm{c}$ and control group I was similar $(P>$ $0.05)$. The expression of abaI in group a was approximately 0.5 -fold higher than that of the control I group, while its expression in group $\mathrm{d}$ was approximately 2 -fold higher. In the cellular environment, the $a b a I$ expression in groups a and b was approximately $40 \%$ higher than that of the control I group, while that in group $\mathrm{d}$ was about 17 times higher than that in control group I.

\section{Discussion}

$\mathrm{Ab}$ infection and colonization co-exist, mainly causing respiratory infections (such as ventilator-associated pneumonia) [17] that seriously endanger human life and quality of life and result in a major economic burden [18]. Elucidating the molecular mechanism of the interaction between $\mathrm{Ab}$ and host cells is of great significance for further understanding the pathogenic mechanism of 


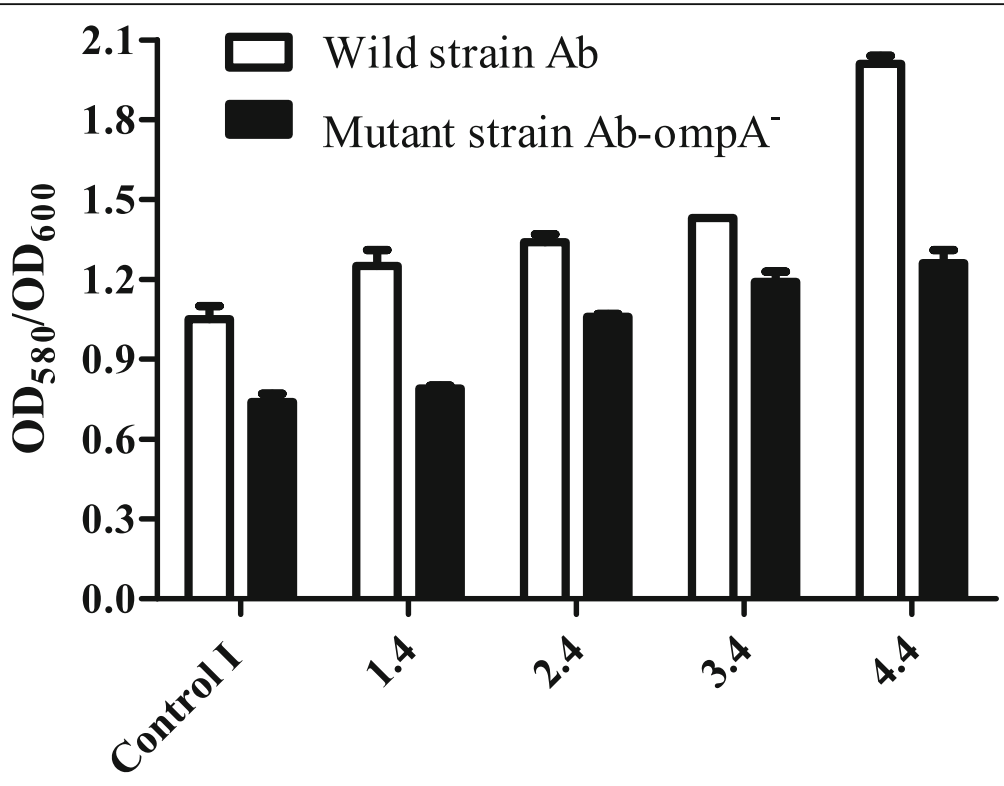

\section{Calcium concentration $(\mathrm{mmol} / \mathrm{L})$}

Fig. 4 Biofilm assay results. Control I: calcium final concentration was $0 \mathrm{mmol} / \mathrm{L}$ (with EDTA treatment). Calcium may promote Ab biofilm formation, and ompA has a positive effect on biofilm formation

this bacteria and proposing new prevention and treatment strategies.

Based on the normal blood calcium concentration of $2.25-2.75 \mathrm{mmol} / \mathrm{L}$, the concentration of calcium in the media used in these experiments was controlled within $1.4-4.4 \mathrm{mmol} / \mathrm{L}$ to simulate the environment of the body. Our study found that exogenous calcium supplementation can promote the proliferation of $\mathrm{Ab}$ and the adherent growth of human respiratory epithelial cells, as well as induce differential expression of Ab-related genes. In addition, calcium also played an important role in host-bacterial interaction, promoting $\mathrm{Ab}$ adhesion/invasion of human respiratory epithelial cells and thereby increasing the degree of bacterial infection in the host cells. The higher the calcium concentration is (especially in the case of high calcium) and the longer the culture duration, the more severe the degree of host cells bacterial infection is. Calcium may affect the host-bacterial interaction through several factors.

RTCA detection is an important technique that can reflect changes of cell morphology (including size, shape, stretching, etc.), number and adhesion. Compared with traditional endpoint detection, RTCA has the advantages of non-invasive and high accurate, as well as providing real-time monitoring, complete TCRPs, and easy operation. It is widely used in cytology research, such as cell migration and invasion assays, cytotoxicity tests, gene regulation and cellmicroenvironment interactions [15, 19-21]. Therefore, the obtained TCRPs can provide better information on the effect of calcium on host-bacterial interaction, which complements our microscopic observations. Interestingly, RTCA detection in the present study found unique "double peak" (calcium-free, Figs. 1c and 2b) and sharp "single peak" (calcium-containing, Fig. 6) phenomena during bacterial infection of epithelial cells. The sharp "single peak" may indicate that calcium stimulation promotes rapid cell growth (observed peak) at the initial stage of bacterial infection. When the number of bacteria reached the critical point, calcium in turn enhanced bacterial adhesion/invasion of epithelial cells, thereby rapidly decreasing the cell index (CI). The mechanism of the "double peak" phenomenon needs to be further studied and analyzed. Possible mechanisms include that cell death was caused by bacteria and cells stimulating, adapting and interacting with each other. Specifically, the bacteria were added to the cell culture environment as exogenous foreign bodies, which stimulated the proliferation of the cells in the initial stage of infection (the appearance of the first peak), but then the bacteria inhibited host cell proliferation due to its own rapid proliferation (the decrease in the first peak). With prolonged host-bacterial interaction, the cells became tolerant to the bacterial inhibition (adaptation) and continued to proliferate (the emergence of the second peak), after which the two competed with one another in the nutrient-rich environment. Additionally, the increasing toxic effects of the bacteria on the epithelial cells resulted in a rapid reduction in the $\mathrm{CI}$ (the decrease in the second peak). 


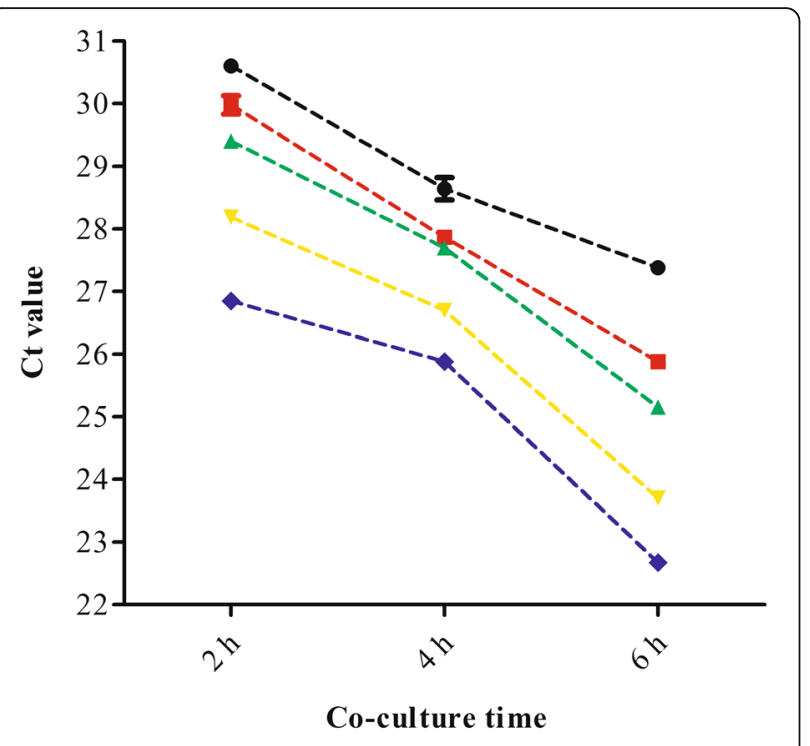

$\rightarrow$ control I

Calcium supplementation final concentration:

$$
\begin{gathered}
- \text { 를. } \quad 1.4 \mathrm{mmol} / \mathrm{L} \\
-7 . \quad 3.4 \mathrm{mmol} / \mathrm{L}
\end{gathered}
$$$$
\text { -«. } 2.4 \mathrm{mmol} / \mathrm{L}
$$$$
\leadsto .4 \mathrm{mmol} / \mathrm{L}
$$

Fig. 5 qPCR results of calcium effect on host-bacterial interaction. $\mathrm{Ab}$ and human respiratory epithelial cells were co-cultured in calcium-supplemented medium for $2 \mathrm{~h}, 4 \mathrm{~h}$ and $6 \mathrm{~h}$, and $1 \times 10^{5}$ cells were isolated for $\mathrm{QPCR}$ detection. Control l: calcium final concentration was $0 \mathrm{mmol} / \mathrm{L}$ (with EDTA treatment). Calcium had positive effect on the interaction between $\mathrm{Ab}$ and epithelial cells. With the increase of calcium concentrations and prolonged coculture times, the amount of Ab invasion into epithelial cells increased (the smaller the $\mathrm{Ct}$ value, the more bacterial invasion to cells)

Ab-ompA, a highly conserved outer membrane protein, is also an important virulence factor that plays an important role in bacterial infection (which is also supported by our research) and causes an up-regulation of epithelial cellular immune response signaling pathway $[16,17]$. It has been shown that Ab-ompA secretes and transmits virulence factors through outer membrane vesicles. Translocation of ompA-containing vesicles into host cells can result in host cell apoptosis, whereas ompA mutants fail to induce cell death [22]. Thus, blocking or inhibiting the expression of Ab-ompA will greatly reduce $\mathrm{Ab}$ adhesion/invasion of host cells [23]. Our studies showed that compared with abiotic environments, Ab-ompA expression is obviously changed in cellular environments. Increased calcium content (especially at $2.4 \mathrm{mmol} / \mathrm{L}$ ) may contribute to the expression of Ab-ompA, which is consistent with our finding that calcium can aggravate bacterial adhesion/ invasion of host cells, while other factors may be involved under high calcium conditions. We found that Ab-ompA expression only changes significantly during host-bacterial interaction indicating that ompA is a virulence factor. Additionally, changing the calcium concentration of the environment may have a significant impact on Ab pathogenicity [13]. OmpA has a positive effect on biofilm formation was also proved in our experiment. Based on the above findings, the increase of calcium concentration may enhance the virulence of bacteria and promote the expression of ompA to some extent. Therefore, if calcium concentration is kept at the lower level of the normal range (2.2-2.4 $\mathrm{mmol} / \mathrm{L}$ ), it may be possible to prevent Ab invasion caused by the up-regulation of ompA expression. We suggest that for patients infected with Acinetobacter baumannii, it is necessary to regularly monitor and strictly control the concentration of serum calcium in order to prevent the deterioration of patients with Acinetobacter baumannii infection.

$\mathrm{Ab}$-bfmRS is a key factor in the survival of $\mathrm{Ab}$ in the environment and is comprised of a sensor kinase (bfmS) and a response regulator (bfmR). The inactivation of bfmRS not only reduces biofilm formation but also leads to the loss of bacterial adhesion to eukaryotic cells [24]. Interestingly, the composition of the culture medium and the interaction of $\mathrm{Ab}$ with abiotic surfaces play a significant role when the BfmRS system is not expressed [12]. In addition, environmental signals are important for the bfmRS regulatory system and biofilm formation, and are involved in inducing the bacterial morphology responsible for interacting with abiotic surfaces [12]. These observations may explain why exogenous calcium supplementation in cellular and abiotic environments has completely different effects onbfmRS expression in our research. In abiotic environments, calcium inhibits the expression of $b f m R S$, which was negatively correlated, while in the cellular environment, calcium promotesbfmRS expression. This is consistent with the fact that calcium may promote biofilm formation and increase $\mathrm{Ab}$ adhesion/invasion. Calcium may be an environmental signaling molecule affecting the expression of $\mathrm{Ab}$ bfmRS. Therefore, increasing the concentration of calcium may promote the formation of biofilm and enhance the bacterial adhesion/invasion of epithelial cells. As Ab-bfmRS expression is controlledby many factors, how calcium causes a down-regulation of $b f m S$ expression in abiotic environments remains to be further studied.

The protein encoded by $a b a I$ is a very important selfinducible synthase of $\mathrm{Ab}$ that produces distinct acylhomoserine lactone (AHL) signals that can up-regulate the expression of abaI through a positive feedback loop to promote the secretion of AHLs and biofilm maturation [25]. Our study found that calcium has a similar 

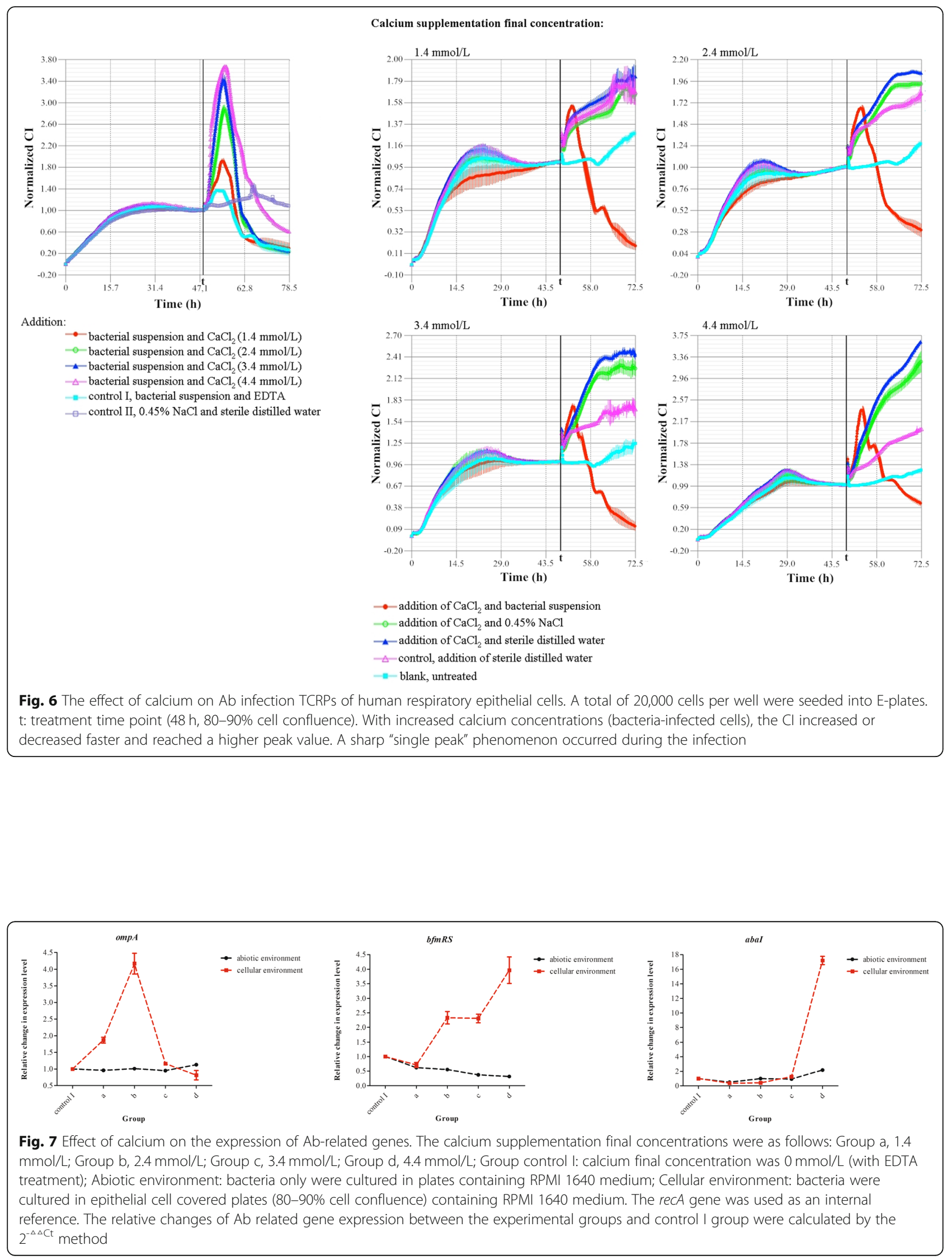
effect on Ab-abaI expression in the cellular and abiotic environments. Low concentrations of calcium $(<2.4$ $\mathrm{mmol} / \mathrm{L}$ ) may inhibit abaI expression, while high concentrations of calcium tend to promote its expression. The change in Ab-abaI expression with high concentrations of calcium in the cellular environment was more significant than in the abiotic environment. Moreover, it is known that calcium may promote biofilm formation. These data suggest that bacterial biofilm formation may be reduced by controlling calcium concentrations (2.2$2.4 \mathrm{mmol} / \mathrm{L}$ ), which may reduce $\mathrm{Ab}$ colonization or infection capacities in the environment.

Acinetobacter baumanniiused in this paper was isolated from hospitalized patients and resistant to a variety of antimicrobial agents. At present, because the drug resistance rate of Acinetobacter baumannii is very high, and the clinical strain research can reflect the real clinical situation and has strong practicability, clinical multidrug-resistant strains were used to investigate the effect of calcium on the interaction between clinical strains and respiratory epithelial cells. However, there are many reports on the interaction between epithelial cells and Acinetobacter baumannii standard strains using either ATCC 19606 or ATCC 17978. The lack of experiments with standard strains is the shortcoming of this paper, so we have provided antimicrobial susceptibility testing results and genome sequencing results about the clinical multidrug-resistant isolate to make the experimental data comparable.

\section{Conclusions}

Since the standard strain of $\mathrm{Ab}$ was not used in the study, the consistency between the results of this paper and previous reports needs to be further verified. According to the results of this experiment, we have come to the following preliminary conclusions. First, with the increase of MOI, $\mathrm{Ab}$ adhesion/invasion of human respiratory epithelial cells was gradually increased. Second, in the initial stage of infection, low concentrations of $\mathrm{Ab}$ have no significant effect on cell growth, and a unique "double peak" phenomenon emerged in the process of infection. Third, calcium may promote $\mathrm{Ab}$ biofilm formation, and $о т р A$ has a positive effect on biofilm formation; calcium may promote the proliferation of $\mathrm{Ab}$ and the adherent growth of human respiratory epithelial cells; furthermore, it can increase the adhesion/invasion of $\mathrm{Ab}$ to epithelial cells by regulating the expression of Ab-related genes (ompA, bfmRS, $a b a I)$. Lastly, calcium also has an impact on the interaction between $\mathrm{Ab}$ and human respiratory epithelial cells, and stimulates cell growth more significantly in the early stage of infection, resulting in a sharp "single peak" phenomenon. The higher the calcium concentration is and the longer the co-culture time is, the more serious the host cells were infected by bacteria. Based on the results of these experiments and the related literature $[13,14]$, it can be speculated that controlling calcium concentrations may play a role in the prevention and treatment of multi-drug resistant $\mathrm{Ab}$ colonization or infection.

\section{Methods \\ Cells and bacteria}

The human respiratory epithelial cells (HPAEpiC,Cat. No. 3200) were purchased from ScienCell Research Laboratories, Inc. (San Diego, California) and maintained in RPMI 1640 medium containing 10\% fetal bovine serum and $100 \mathrm{U} / \mathrm{ml}$ penicillin/streptomycin (GIBCO) at $37{ }^{\circ} \mathrm{C}$ and $5 \% \mathrm{CO}_{2}$. The use of HPAEpiC cells can better reflect the colonization or infection of Acinetobacter baumannii in human respiratory tract and is close to the human environment. The clinical isolate of multidrugresistant $\mathrm{Ab}$ (Additional file 5: Table S2) was originally collected from the sputum of patient hospitalized in Hangzhou First People's Hospital, China. After identification of genome sequencing (Sangon Biotech Co., Ltd., Shanghai; the SRA accession: PRJNA523637), the bacteria were inoculated to blood agar plates for $18-20 \mathrm{~h}$ at $37^{\circ} \mathrm{C}$, and then single colonies were picked to suspend in $0.45 \%$ sodium chloride solution for preparing bacterial suspension. The bacteria per $\mathrm{ml}$ was calculated based on $1 \mathrm{McF}=2 \times 10^{8} \mathrm{CFU} / \mathrm{ml}$.

\section{Host-bacterial co-culture At different MOls}

The range of bacterial MOIs was selected according to previous studies [15]. A $1 \mathrm{ml}$ aliquot of HPAEpiC $(2 \times$ $10^{5}$ cells $/ \mathrm{ml}$ ) was seeded into six-well plates containing RPMI 1640 medium. Immediately, $100 \mu$ l of different concentrations of bacteria $\left(2 \times 10^{6}, 2 \times 10^{7}, 1 \times 10^{8}\right.$ and $2 \times 10^{8} \mathrm{CFU} / \mathrm{ml}$, corresponding to the MOIs $1,10,50$ and 100 , respectively) were inoculated into each well, and $0.45 \% \mathrm{NaCl}$ was used as the normal control. The effects of $\mathrm{Ab}$ on the morphology and proliferation of epithelial cells at different MOIs and co-culture time points $(2 \mathrm{~h}, 4 \mathrm{~h}, 6 \mathrm{~h}$ and $8 \mathrm{~h}$ ) were observed by an IX70 bright field inverted microscopy (Olympus Optical Co., Ltd., Japan) at a magnification of 30x. Meanwhile, we identified the live and dead epithelial cells according to the LIVE-DEAD viability/cytotoxicity assay kit instructions (Life Technologies, Grand Island, NY, USA) and detected using an IX71 inverted microscopy with Nomarski optics (Olympus Optical Co., Ltd., Japan). Based on these observations, a suitable time period for the host-bacterial co-culture was selected for subsequent experiments.

The liquid in each well of the six-well plates was carefully discarded at the end of the indicated host-bacterial 
co-culture time period. Before digestion with trypsin solution for $1-2 \mathrm{~min}$ at $37^{\circ} \mathrm{C}$, the cells were washed once with phosphate buffer saline (PBS). The cells were then harvested by centrifugation $(100 \times \mathrm{g}, 5 \mathrm{~min})$ and washed twice with PBS. Finally, bacterialDNA was extracted from $1 \times 10^{5}$ cells based on procedures described by Chen et al [26]. qPCR was performed with SYBR Premix Ex Taq II (TaKaRa Bio Inc., Shiga, Japan) on an ABI 7500 real-time PCR instrument (Applied Biosystems, United States) according to the manufacturer's instructions. Each test $(50-\mu l$ volume) was performed in triplicate. Sterile distilled water served as a negative control, and bacterialDNA served as a positive control. Primer sequences for the target gene (ompA, outer membrane protein A) were as follows: 5'-CACAGATAACACTG GTCCACG-3' and 5'-GAATACACGACGGTTCATAGC$3^{\prime}$. The changes in Ab invasion of epithelial cells (including strong adhesion) at different MOIs were anaylsed by comparing the $\mathrm{Ct}$ values obtained.

Detailed RTCA (real time cellular analysis) experimental procedures have been previously described $[15,19,20]$. Briefly, $50 \mu \mathrm{l}$ of medium was added to 16-well E-plates (specific cell culture plates for RTCA) to obtain background readings, which were followed by the addition of $100 \mu \mathrm{l}$ of a cell suspension $\left(2 \times 10^{5}\right.$ cells/ml). After the EPlate was incubated at room temperature for $30 \mathrm{~min}$, and $10 \mu \mathrm{l}$ of different concentrations of bacterial suspension or $0.45 \% \mathrm{NaCl}$ was added to the wells containing cells. The E-Plates were placed onto the reader in the incubator for continuous recording of the CI. The cells were monitored every $5 \mathrm{~min}$ for $72 \mathrm{~h}$ to obtain TCRPs. The data were collected from three multiple-well duplicates and presented as the $\mathrm{CI}$ normalized $(\mathrm{CI}=1.00)$ to the last time point before intervention. Additionally, a suitable bacterial concentration was selected for subsequent experiments based on the above results.

\section{In different states of cell incubation}

The purpose of this experiment was to observe the effect of Acinetobacter baumannii on cell proliferation under different cell culture conditions and cell adherent growth conditions. In other words, what kind of cell incubation (cell suspension, cell partial adherent fusion, cell complete adherent fusion) is more suitable to add bacterial suspension to cell petri dish (including cell and cell culture medium) to study host-bacterial interaction. This experiment was divided into three groups of different cell incubation states.

Cell suspension: the purpose of this experimental group was to observe the effect on the adhesion of $\mathrm{Ab}$ to host cell under initial suspension state of cell suspension added to six-well plates $(0 \mathrm{~h}) ; 30-40 \%$ cell confluence: the purpose of this experimental group was to observe the effect of Acinetobacter baumannii on epithelial cells without growth space restriction (The cells have been cultured for $24 \mathrm{~h}$ ); $80-90 \%$ cell confluence: the purpose of this experimental group was to observe the effect of Acinetobacter baumannii on epithelial cells under the cell incubation state of $80-90 \%$ cell confluency after 48 $\mathrm{h}$ of cell culture, this state was close to the human environment.

A total of $2 \mathrm{ml}$ of cells $\left(2 \times 10^{5}\right.$ cells $\left./ \mathrm{ml}\right)$ were seeded into six-well plates containing RPMI 1640 medium. $200 \mu \mathrm{l}$ of the indicated concentration of bacteria was added to wells containing cells in different incubation states (cell suspension, $30-40 \%$ cell confluence and 80 $90 \%$ cell confluence) and $0.45 \% \mathrm{NaCl}$ was used as the normal control. An inverted microscopy was used to observe the dynamic process of the interaction between $\mathrm{Ab}$ and epithelial cells at different states of cell incubation $(2 \mathrm{~h}, 4 \mathrm{~h}, 6 \mathrm{~h}, 8 \mathrm{~h}$ and $24 \mathrm{~h})$.

RTCA experimental procedures were as described above. A total of $10 \mu \mathrm{l}$ of the above mentioned bacterial suspensions, $0.45 \% \mathrm{NaCl}$ or sterile distilled water was added to wells containing cells at different incubation states (cell suspension, 30-40\% cell confluence and 80$90 \%$ cell confluence). Wells without intervention were used as the blank control. The interaction between $\mathrm{Ab}$ and human respiratory epithelial cells were evaluated based on the TCRP results and microscopic imaging.

\section{Effect of calcium on host-bacterial interaction Ab growth assays}

A total of $400 \mu$ l of each of the indicated concentrations of bacteria and different concentrations $(12 \mathrm{mmol} / \mathrm{L}, 24$ $\mathrm{mmol} / \mathrm{L}, 36 \mathrm{mmol} / \mathrm{L}$ and $48 \mathrm{mmol} / \mathrm{L}$ ) of a calcium chloride solution $\left(\mathrm{CaCl}_{2}\right)$ were added to wells containing $2 \mathrm{ml}$ of RPMI 1640 medium. A $400 \mu \mathrm{l}$ aliquot of each of the bacterial suspensions and EDTA solution $(5 \mathrm{mmol} / \mathrm{L})$ was used as the normal control I (taking into account the presence of calcium in RPMI, the final calcium concentrations in experimental groups were $1.4 \mathrm{mmol} / \mathrm{L}$, $2.4 \mathrm{mmol} / \mathrm{L}, 3.4 \mathrm{mmol} / \mathrm{L}$ and $4.4 \mathrm{mmol} / \mathrm{L}$, respectively, and the normal control I was $0 \mathrm{mmol} / \mathrm{L}$ ). The effect of different concentrations of calcium and culture times (2 $\mathrm{h}, 4 \mathrm{~h}, 6 \mathrm{~h}, 8 \mathrm{~h}, 16 \mathrm{~h}$ and $24 \mathrm{~h}$ ) on the proliferation of $\mathrm{Ab}$ were measured at $600 \mathrm{~nm}$ using a microplate reader (Sunrise, Tecan, Switzerland). Each experiment was performed in triplicate.

\section{Experiments on the differential expression of Ab-related genes}

The sequences of Ab-related genes were selected according to previous studies [12, 16, 27, 28]. Specifically, the recA (internal reference), ompA(outer membrane protein A), $b f m R S$ (two-component regulatory system) andabaI (autoinducer synthase) sequences were downloaded from GenBank. The primers (Table 2) for reverse 
Table 2 Primers for RT-qPCR

\begin{tabular}{|c|c|c|c|}
\hline Gene ID $^{a}$ & Primers & Sequences $\left(5^{\prime}-3^{\prime}\right)$ & Product length (bp) \\
\hline \multicolumn{4}{|l|}{ Reference gene } \\
\hline AF251469.1 & $\begin{array}{l}\text { recA-F } \\
\text { recA-R }\end{array}$ & ACGCCCTAGACCCTCAATAT AGAGTCACCCATCTCACCTTC & 197 \\
\hline \multicolumn{4}{|l|}{ Target gene } \\
\hline AY485227.1 & $\begin{array}{l}\text { ompA-F } \\
\text { ompA-R }\end{array}$ & CACAGATAACACTGGTCCACG GAATACACGACGGTTCATAGC & 190 \\
\hline AY838282.1 & $\begin{array}{l}\text { bfmRS-F } \\
\text { bfmRS-R }\end{array}$ & AACAAAGTTCGGATTACGGG TCATCTAAACGGGCAAAGG & 128 \\
\hline EU334497.1 & $\begin{array}{l}\text { abal-F } \\
\text { abal-R }\end{array}$ & CTATTCCCTGCTCACCAGA CCCGCAGCACGTAATAAAC & 208 \\
\hline
\end{tabular}

${ }^{a}$ : GenBank

transcription quantitative PCR (RT-qPCR) were designed using the Primer Premiers 5.0 software, selected based on a BLAST sequence comparison, and synthesized by Life Technology (Shanghai, China). After incubation for the indicated time period described above, all bacteria were collected and total RNA was isolated from each group using an AxyPrep Miniprep Kit (Corning Inc., NY, USA) according to the manufacturer's instructions. The concentration and purity $\left(\mathrm{OD}_{260} / \mathrm{OD}_{280}\right.$ of approximately 2.0) of the RNA samples were measured using a NanoDrop 2000 spectrophotometer (Thermo Fisher Scientific, Wilmington, USA). RT-qPCR was performed with the One Step SYBR PrimeScript PLUS RT-PCR Kit (TaKaRa) on an ABI 7500 real-time PCR instrument according to the manufacturer's instructions. Each test ( $50 \mu \mathrm{l}$ volume, $20 \mathrm{ng}$ of RNA template) was performed in triplicate. RNase free distilled water served as negative control I and templates treated with RNase served as negative control II. The differential expression of Ab-related genes (ompA, bfmRSand abaI) under different calcium concentrations was anaylsed by comparing the resulting $\mathrm{Ct}$ values.

\section{Ab biofilm assays}

Mutant strains of $\mathrm{Ab}$ deficient in ompA (Ab-ompA ${ }^{-}$) were constructed and modified according to the conjugative transfer and parental conjugation methods [29, 30]. Briefly, a modified pMO130-Tel ${ }^{\mathrm{R}}$ with the fragments corresponding to the regions up and downstream of the ompA gene generated from genome of Abwas constructed. The resultant plasmid was then transformed into theE.coli $S 17-1 \lambda$ pir competent cells. Then, trans-conjugation was performed between E.coli S17-1 $\lambda$ pir donor strain and $A b$ recipient strain to transfer and integrate pMO130-Tel ${ }^{\mathrm{R}}$-ompA (Up/Down) into the chromosome of Ab.Donor and recipient strains were plated onto LB agar containing tellurite $(30 \mathrm{mg} / \mathrm{L})$ and gentamicin $(25 \mathrm{mg} / \mathrm{L})$ and incubated at $37^{\circ} \mathrm{C}$ overnight. $0.45 \mathrm{~mol} / \mathrm{L}$ catechol solution was sprayed on the surface of the plate, and yellow clones were picked for
PCR identification. The second selection was then performed by incubating $\mathrm{Ab}$ on $10 \%$ sucrose with saltfree LB agar plates, stayed overnight at $37^{\circ} \mathrm{C}$ to identify sucrose-resistant sensitive clones, then analyzed by PCR and sequencing to confirm that the target gene was excised, resulting in an unmarked in-frame deletion. A single clone with no $\operatorname{ompA}$ sequence was saved as $\mathrm{Ab}$-ompA $\mathrm{A}^{-}$. $\mathrm{Ab}$ and $\mathrm{Ab}$-ompA ${ }^{-}$isolates were added separately to 96-well plates containing RPMI 1640 medium of different calcium concentrations (range from 0 to $4.4 \mathrm{mmol} / \mathrm{L}$ ). The biofilm formation was measured based on procedures outlined by Selasiet al [31]. with some modifications. After $24 \mathrm{~h}$, the liquid in each well was carefully discarded and washed three times with PBS. Then, the plates were air-dried and stained with crystal violet $(0.1 \% \mathrm{v} / \mathrm{v})$ for $20 \mathrm{~min}$. Finally, the plates were washed three times with PBS, air-dried and decolorized with ethanol $(95 \% \mathrm{v} / \mathrm{v})$ for $20 \mathrm{~min}$. The turbidity was measured at $580 \mathrm{~nm}$ using the Tecan Sunrise microplate reader. Additionally, the turbidity was also measured at $600 \mathrm{~nm}$ before biofilm mass staining to compensate for bacterial growth differences. Biofilm formation was quantified by calculating the ratio of $\mathrm{OD}_{580} / \mathrm{OD}_{600}$. Each experiment was performed in triplicate.

\section{Experiments on the morphology and proliferation of epithelial cells}

A $2 \mathrm{ml}$ cell suspension $\left(2 \times 10^{5}\right.$ cells $\left./ \mathrm{ml}\right)$ was seeded into six-well plates and allowed to attach and grow for $48 \mathrm{~h}$ to reach the platform stage $(80-90 \%$ cell confluence) before the addition of a $400 \mu$ l aliquot of each of sterile distilled water and different concentrations of $\mathrm{CaCl}_{2}$. Additionally, a $400 \mu \mathrm{l}$ aliquot of each of sterile distilled water and EDTA was used as the normal control. The effects of different concentrations of calcium and culture times $(2 \mathrm{~h}, 4 \mathrm{~h}, 6 \mathrm{~h}, 8 \mathrm{~h}$ and 24 h) on the morphology and proliferation of epithelial cells were observed by inverted microscopy. 
RTCA experimental procedures were as described above. After incubation for $48 \mathrm{~h}$, cells were treated with a $20 \mu \mathrm{l}$ aliquot of each of sterile distilled water and different concentrations of $\mathrm{CaCl}_{2}$ or a $20 \mu \mathrm{l}$ aliquot of each of sterile distilled water and EDTA. A well without intervention was used as a blank control. The effects of calcium on the morphology and proliferation of epithelial cells were evaluated based on the TCRP results and microscopic imaging.

\section{Experiments on host-bacteria interactions}

A $2 \mathrm{ml}$ cell suspension $\left(2 \times 10^{5}\right.$ cells $\left./ \mathrm{ml}\right)$ was seeded into wells and allowed to attach and grow for $48 \mathrm{~h}$ before the addition of a $400 \mu \mathrm{l}$ aliquot of each of the indicated bacterial concentrations and different concentrations of $\mathrm{CaCl}_{2}$. Additionally, a $400 \mu \mathrm{l}$ aliquot of each of the bacterial suspensions and EDTA was used as the normal control I. The effect of $\mathrm{Ab}$ on the morphology and proliferation of epithelial cells with different calcium concentrations and co-culture times $(2 \mathrm{~h}, 4 \mathrm{~h}, 6 \mathrm{~h}, 8 \mathrm{~h}$ and $24 \mathrm{~h}$ ) were observed by inverted microscopy.

According to the procedures described above, total bacterial RNA was isolated from each group and RTqPCR was performed after host cells and bacteria were co-cultured for the indicated time period. The expression of Ab-related genes in the biotic environment under different calcium concentrations was anaylsed by comparing the $\mathrm{Ct}$ values obtained.

In addition, a $400 \mu \mathrm{l}$ aliquot of each of sterile distilled water and $0.45 \% \mathrm{NaCl}$ was used as the normal control II. All the liquid in the wells was carefully discarded after a $2 \mathrm{~h}, 4 \mathrm{~h}$ or $6 \mathrm{~h}$ incubation, as described above. Before digestion, the cells were washed three times with PBS. Other procedures, including bacterial DNA extraction and $\mathrm{qPCR}$ were carried out as described above. The changes of $\mathrm{Ab}$ invasion to epithelial cells (including strong adhesion) under different calcium concentrations and co-culture times was anaylsed by comparing the $\mathrm{Ct}$ values obtained.

RTCA experimental procedures were as described above. After the cells (20,000 cells per well) were incubated for $48 \mathrm{~h}$, the two part experiment was carried out as follows:

1. A $20 \mu \mathrm{l}$ aliquot of each of the abovementioned bacterial suspensions and different concentrations of $\mathrm{CaCl}_{2}$ was added to the wells; the bacterial suspensions and EDTA was used as the normal control I; sterile distilled water and $0.45 \% \mathrm{NaCl}$ was used as the normal control II.

2. A $20 \mu \mathrm{l}$ aliquot of each of different concentrations of $\mathrm{CaCl}_{2}$ and the bacterial suspension/0.45\% NaCl/ sterile distilled water was added to the wells; a total of $20 \mu \mathrm{l}$ of sterile distilled water was added as the normal control. Wells without intervention were used as the blank control.

The effect of calcium on the host-bacterial interactions was evaluated based on the TCRP results, qPCR and microscopic imaging.

\section{Statistical analysis}

The data are presented as the means $\pm \mathrm{SD}$. One-way analysis of variance (ANOVA) and the StudentNewman-Keuls (SNK) test were applied to compare and analyse the changes in $\mathrm{Ct}$ values at different MOIs and the effects of calcium on the expression of $\mathrm{Ab}$ related genes. Two-way ANOVA and the SNK test were applied to analyse the effects of calcium on biofilm formation of different Ab strains. The effects of different calcium concentrations and culture times on the $\mathrm{CI}$ of epithelial cells were analysed using multivariate ANOVA with repeated measures and the SNK test. Univariate ANOVA with repeated measures and the SNK test were used to compare and analyse the effects of different calcium concentrations and co-culture times on $\mathrm{Ab}$ invasion (including strong adhesion) of epithelial cells (Ct values). $P<0.05$ was considered to be statistically significant.

\section{Supplementary information}

Supplementary information accompanies this paper at https://doi.org/10. 1186/s12866-019-1643-z

Additional file 1: Figure. S1. Co-culture of Acinetobacter baumannii (Ab) and epithelial cells.

Additional file 2: Figure. S2. Effect of calcium on TCRPs of human respiratory epithelial cells.

Additional file 3: Table S1. Effect of calcium concentrations on the $\mathrm{Cl}$ of epithelial cells.

Additional file 4: Figure. S3. Microscopy observations of the effect of calcium on host-bacterial interactions.

Additional file 5: Table S2. Results of antimicrobial susceptibility testing of Ab used in this study.

\section{Abbreviations}

Ab: Acinetobacter baumanii; AHL: N-acyl homoserine lactone; ANOVA: Analysis of variance; Cl: Cell index; Ct: Cycle threshold; MOI: Multiplicity of infection; qPCR: quantitative PCR; RTCA: Real time cellular analysis; RT-qPCR; : Reverse transcription quantitative PCR; SNK: StudentNewman-Keuls; TCRP: Time-dependent cell response profile

\section{Acknowledgements}

Not applicable.

\section{Authors' contributions}

DJY conceived the study, supervised the experiments, wrote the manuscript and secured funding. YC conceived and carried out all experiments, data analysis, and manuscript writing. TJS and SHF performed the experiments and edited the manuscript. PP, JHJ, TTC performed the experiments and analyzed data. HTW participated in the study design, supervised the experiments and secured funding. All authors have read and approved the final manuscript. 


\section{Funding}

This work was supported by the Natural Science Foundation of Zhejiang Province (No. LY17H190001 and LY17H090009), the National Natural Science Foundation of China (No. 81930111),Public Technology Application Research of Zhejiang Province (No. 2016F82G2010036) and Health and Family Planning Commission of Hangzhou Manicipality (No. 2018ZD001). The funding source had no role in the study design, analysis, collection, data interpretation and manuscript writing.

\section{Availability of data and materials}

All data generated or analysed during this study are included in this published article.

\section{Ethics approval and consent to participate}

This study was approved by the Ethics Review Committee of Hangzhou First People's Hospital, China. With written permission from the patient, the clinical isolate of multidrug-resistant $\mathrm{Ab}$ was collected from his sputum.

\section{Consent for publication}

Not applicable.

\section{Competing interests}

The authors declare that they have no competing interests.

\section{Author details}

${ }^{1}$ Hangzhou First People's Hospital, Zhejiang Chinese Medical University, Hangzhou, China. ${ }^{2}$ Department of Clinical Laboratory, Zhejiang Hospital, Hangzhou, China. ${ }^{3}$ Zhejiang University School of Medicine, Hangzhou, China. ${ }^{4}$ Zhejiang Chinese Medical University, Hangzhou, China.

\section{Received: 26 August 2019 Accepted: 14 November 2019}

Published online: 27 November 2019

\section{References}

1. Wong D, Nielsen TB, Bonomo RA, Pantapalangkoor P, Luna B, Spellberg B. Clinical and pathophysiological overview of Acinetobacter infections: a century of challenges. Clin Microbiol Rev. 2017;30(1):409-47.

2. Kroger C, Kary SC, Schauer K, Cameron AD. Genetic Regulation of Virulence and Antibiotic Resistance in Acinetobacter baumannii. Genes. 2016;8(1). https://doi.org/10.3390/genes8010012.

3. Kentache T, Ben Abdelkrim A, Jouenne T, De E, Hardouin J. Global dynamic proteome study of a pellicle-forming Acinetobacter baumannii strain. Mol Cell Proteomics. 2017:16(1):100-12.

4. Peleg AY, Seifert $H$, Paterson DL. Acinetobacter baumannii: emergence of a successful pathogen. Clin Microbiol Rev. 2008:21(3):538-82.

5. Dijkshoorn L, Nemec A, Seifert $H$. An increasing threat in hospitals: multidrug-resistant Acinetobacter baumannii. Nat Rev Microbiol. 2007; 5(12):939-51.

6. Chang $\mathrm{HL}$, Tang $\mathrm{CH}$, Hsu YM, Wan L, Chang YF, Lin CT, Tseng YR, Lin YJ, Sheu JJ, Lin CW, et al. Nosocomial outbreak of infection with multidrugresistant Acinetobacter baumannii in a medical center in Taiwan. Infect Control Hosp Epidemiol. 2009;30(1):34-8.

7. Apisarnthanarak A, Pinitchai U, Thongphubeth K, Yuekyen C, Warren DK, Fraser VJ. A multifaceted intervention to reduce pandrug-resistant Acinetobacter baumannii colonization and infection in 3 intensive care units in a Thai tertiary care center: a 3-year study. Clin Infect Dis. 2008; 47(6):760-7

8. Azim A, Dwivedi M, Rao PB, Baronia AK, Singh RK, Prasad KN, Poddar B, Mishra A, Gurjar M, Dhole TN. Epidemiology of bacterial colonization at intensive care unit admission with emphasis on extended-spectrum beta-lactamase- and metallo-beta-lactamase-producing gram-negative bacteria--an Indian experience. J Med Microbiol. 2010;59(Pt 8):955-60.

9. SweSwe-Han K, Mlisana KP, Pillay M. Analysis of clinical and microbiological data on Acinetobacter baumannii strains assist the preauthorization of antibiotics at the patient level for an effective antibiotic stewardship program. J Infect Public Health. 2017;10(5):608-16.

10. Stanley NR, Lazazzera BA. Environmental signals and regulatory pathways that influence biofilm formation. Mol Microbiol. 2004;52(4):917-24.

11. Howard A, O'Donoghue M, Feeney A, Sleator RD. Acinetobacter baumannii: an emerging opportunistic pathogen. Virulence. 2012;3(3):243-50.
12. Gaddy JA, Actis LA. Regulation of Acinetobacter baumannii biofilm formation. Future Microbiol. 2009:4(3):273-8.

13. Smani Y, Docobo-Perez F, McConnell MJ, Pachon J. Acinetobacter baumannii-induced lung cell death: role of inflammation, oxidative stress and cytosolic calcium. Microb Pathog. 2011;50(5):224-32.

14. Lee HW, Koh YM, Kim J, Lee JC, Lee YC, Seol SY, Cho DT, Kim J. Capacity of multidrug-resistant clinical isolates of Acinetobacter baumannii to form biofilm and adhere to epithelial cell surfaces. Clin Microbiol Infect. 2008; 14(1):49-54.

15. Mou X, Wan S, Li Y, Zhang S, Sun M, Liu F, Fu H, Zhang X, Liu H, Cao Q, et al. Phenotypic pattern-based assay for dynamically monitoring host cellular responses to Salmonella infections. PLoS One. 2011;6(11):e26544.

16. Mortensen BL, Skaar EP. Host-microbe interactions that shape the pathogenesis of Acinetobacter baumannii infection. Cell Microbiol. 2012; 14(9):1336-44.

17. McConnell MJ, Actis L, Pachon J. Acinetobacter baumannii: human infections, factors contributing to pathogenesis and animal models. FEMS Microbiol Rev. 2013;37(2):130-55

18. Lee $\mathrm{H}$, Lee $\mathrm{H}$. Clinical and economic evaluation of multidrug-resistant Acinetobacter baumannii colonization in the intensive care unit. Infect Chemother. 2016;48(3):174-80.

19. Qin S, Wang X, Wu H, Xiao P, Cheng H, Zhang X, Ke Y. Cell-based phenotypic screening of mast cell degranulation unveils kinetic perturbations of agents targeting phosphorylation. Sci Rep. 2016:6:31320.

20. Fu H, Fu W, Sun M, Shou Q, Zhai Y, Cheng H, Teng L, Mou X, Li Y, Wan S, et al. Kinetic cellular phenotypic profiling: prediction, identification, and analysis of bioactive natural products. Anal Chem. 2011;83(17):6518-26.

21. Song Y, Li L, Ou Y, Gao Z, Li E, Li X, Zhang W, Wang J, Xu L, Zhou Y, et al. Identification of genomic alterations in oesophageal squamous cell cancer. Nature. 2014;509(7498):91-5.

22. Jin JS, Kwon SO, Moon DC, Gurung M, Lee JH, Kim SI, Lee JC. Acinetobacter baumannii secretes cytotoxic outer membrane protein a via outer membrane vesicles. PLoS One. 2011:6(2):e17027.

23. Vila-Farres X, Parra-Millan R, Sanchez-Encinales V, Varese M, AyerbeAlgaba R, Bayo N, Guardiola S, Pachon-Ibanez ME, Kotev M, Garcia J, et al. Combating virulence of gram-negative bacilli by OmpA inhibition. Sci Rep. 2017:7(1):14683.

24. Liou ML, Soo PC, Ling SR, Kuo HY, Tang CY, Chang KC. The sensor kinase BfmS mediates virulence in Acinetobacter baumannii. J Microbiol Immunol Infect. 2014;47(4):275-81.

25. Niu C, Clemmer KM, Bonomo RA, Rather PN. Isolation and characterization of an autoinducer synthase from Acinetobacter baumannii. J Bacteriol. 2008; 190(9):3386-92.

26. Chen $Y$, He H, Pan P, He S, Dong X, Chen Y, Wang S, Yu D. Rapid and combined detection of mycoplasma pneumoniae, Epstein-Barr virus and human cytomegalovirus using AllGlo quadruplex quantitative PCR. J Med Microbiol. 2016;65(7):590-5

27. Yang $Q$ Rui Y. Two Multiplex Real-Time PCR Assays to Detect and Differentiate Acinetobacter baumannii and Non- baumannii Acinetobacter spp. Carrying blaNDM, blaOXA-23-Like, blaOXA-40-Like, blaOXA-51-Like, and blaOXA-58-Like Genes. PloS one. 2016;11(7):e0158958.

28. Bartual SG, Seifert H, Hippler C, Luzon MA, Wisplinghoff H, Rodriguez-Valera F. Development of a multilocus sequence typing scheme for characterization of clinical isolates of Acinetobacter baumannii. J Clin Microbiol. 2005:43(9):4382-90.

29. Amin IM, Richmond GE, Sen P, Koh TH, Piddock LJ, Chua KL. A method for generating marker-less gene deletions in multidrug-resistant Acinetobacter baumannii. BMC Microbiol. 2013;13:158

30. Oh MH, Lee JC, Kim J, Choi CH, Han K. Simple method for Markerless gene deletion in multidrug-resistant Acinetobacter baumannii. Appl Environ Microbiol. 2015;81(10):3357-68.

31. Selasi GN, Nicholas A, Jeon H, Na SH, Kwon HI, Kim YJ, Heo ST, Oh MH, Lee JC. Differences in biofilm mass, expression of biofilm-associated genes, and resistance to desiccation between epidemic and sporadic clones of Carbapenem-resistant Acinetobacter baumannii sequence type 191. PLoS One 2016:11(9):e0162576.

\section{Publisher's Note}

Springer Nature remains neutral with regard to jurisdictional claims in published maps and institutional affiliations. 